\section{A. ARS BILDUMA ISSN 1989-9262 UPV/EHU Press}

ARSBILDUMA (CC BY-NC-ND 4.0)

https://doi.org/10.1387/ars-bilduma.21394 BIBLID [(2020), 10; 171-187]

Recibido: 17/01/2020 Aceptado: 12/03/2020

\section{KEPA SOJO GIL}

Universidad del País Vasco (UPV/EHU)

Facultad de Letras

Paseo de la Universidad, 5

01006 Vitoria-Gasteiz (Álava)

kepa.sojo@ehu.eus

https://orcid.org/0000-0002-3384-3608

Este artículo ha sido realizado en el marco del proyecto de investigación del Ministerio de Economía y Competitividad del Gobierno de España HAR201788543-P: "Estudio de la cultura audiovisual del tardofranquismo (1970-1975). Proceso de modernización y transiciones en cine, fotografía, televisión, comic y diseño".

\title{
ESA PAREJA FELIZ (1951) DE BERLANGA Y BARDEM Y SUS REFERENTES CINEMATOGRÁFICOS Y LITERARIOS
}

\section{ESA PAREJA FELIZ (1951) OF BERLANGA AND BARDEM AND THEIR CINEMA- TOGRAPHIC AND LITERARY REFERENCES}

\section{ESA PAREJA FELIZ (1951), BERLANGA ETA BARDEM-EN FILMA ETA BERE ERRE- FERENTE ZINEMATOGRAFIKO ETA LITERARIOAK}

\section{RESUMEN}

Esa pareja feliz es una película clave para comprender el cine disidente al franquismo que reacciona ante el panorama cinematográfico de la postguerra española. Sobre este filme se ha hablado mucho pero nadie ha analizado los referentes cinematográficos y literarios que inspiraron a Berlanga y Bardem. Tan sólo han aparecido esos referentes citados por los propios directores en algunas publicaciones antiguas. Este artículo pretende analizar, el grado de influencia cinematográfica y literaria recibida por Esa pareja feliz, as como la repercusión ejercida por este filme en obras posteriores.

PALABRAS CLAVE

Berlanga; Bardem; franquismo; cine español; comunismo; censura; clandestinidad.

\section{ABSTRACT}

Esa pareja feliz is a key film to understand the dissident cinema to Francoism that reacts to the cinematographic panoram of the Spanish post-war period. Much has been said about this film, but no one has analyzed the cinematographic and literary references that inspired Berlanga and Bardem. Only those references quoted by the directors themselves have appeared in some old publications. This article tries to analyze the degree of cinematographic and literary influence received by Esa pareja feliz, as well as the repercussion exerted by this film in subsequent works.

\section{KEYWORDS}

Berlanga; Bardem; Francoism; Spanish cinema; communism; censure; secrecy.

\section{LABURPENA}

Esa pareja feliz gerraosteko Espainiako zinemaren aurrean zinemagintzari erreakzionatzen dion frankismoaren zinema disidentea ulertzeko funtsezko filma da. Film honi buruz asko esan da, baina inork ez du Berlanga eta Bardem inspiratu zituen erreferentzia zinematografikoak eta literarioak aztertu. Zuzendariek berak aipatutako aipamenak baino ez dira agertu argitalpen zahar batzuetan. Artikulu honetan, Esa pareja feliz filmak izan duen eragin zinematografiko eta literarioa zein den aztertzen saiatzen da, baita pelikula honek gerora egindako lanetan izan duen eragina ere.

\section{GAKO-HITZAK}

Berlanga; Bardem; frankismoa; espainiar zinema; komunismoa; zentsura; klandestinitatea. 


\section{INTRODUCCIÓN}

Sobre Esa pareja feliz (1951), una de las obras cinematográficas más importantes del cine español del franquismo se ha hablado e investigado mucho, al ser un filme realizado por Juan Antonio Bardem y Luis García Berlanga, dos de los cineastas más referenciados del cine español. Se ha analizado la importancia que tiene la película como elemento de ruptura con el cine español de los 40, se ha mencionado la impronta regeneracionista de esta obra y algunas otras del momento como Bienvenido Mister Marshall (1952) ${ }^{1}$, que ponen en tela de juicio la situación de España en la segunda década del franquismo, $y$ se ha estudiado la crítica al cine historicista que supone la secuencia inicial del filme en que se parodia a una película tipo Locura de amor (1948) (Fig. 1). Sin embargo, poco se ha hablado de los referentes cinematográficos y literarios que han funcionado como fuente de inspiración para que Bardem y Berlanga escribieran el guion de la película y la filmarán posteriormente. Los títulos de las películas que han inspirado a los directores tan sólo han sido citados telegráficamente en algunas ocasiones por ellos mismos ${ }^{3}$. Nadie ha profundizado en la relación entre los modelos originales que han inspirado Esa pareja feliz y su comparación con la obra inicial de Bardem y Berlanga. Es por ello por lo que consideramos interesante analizar las películas, cineastas y tendencias cinematográficas y literarias y compararlas con la obra que nos ocupa. Ese es el objetivo principal de esta publicación. Antes de ello, es preciso ubicar el filme de Berlanga y Bardem dentro del contexto fílmico de la España de inicios de los 50, así como repasar la filmografía de los dos directores en este período, y comentar algunas cuestiones relativas a la génesis y a la repercusión de la obra en su momento.

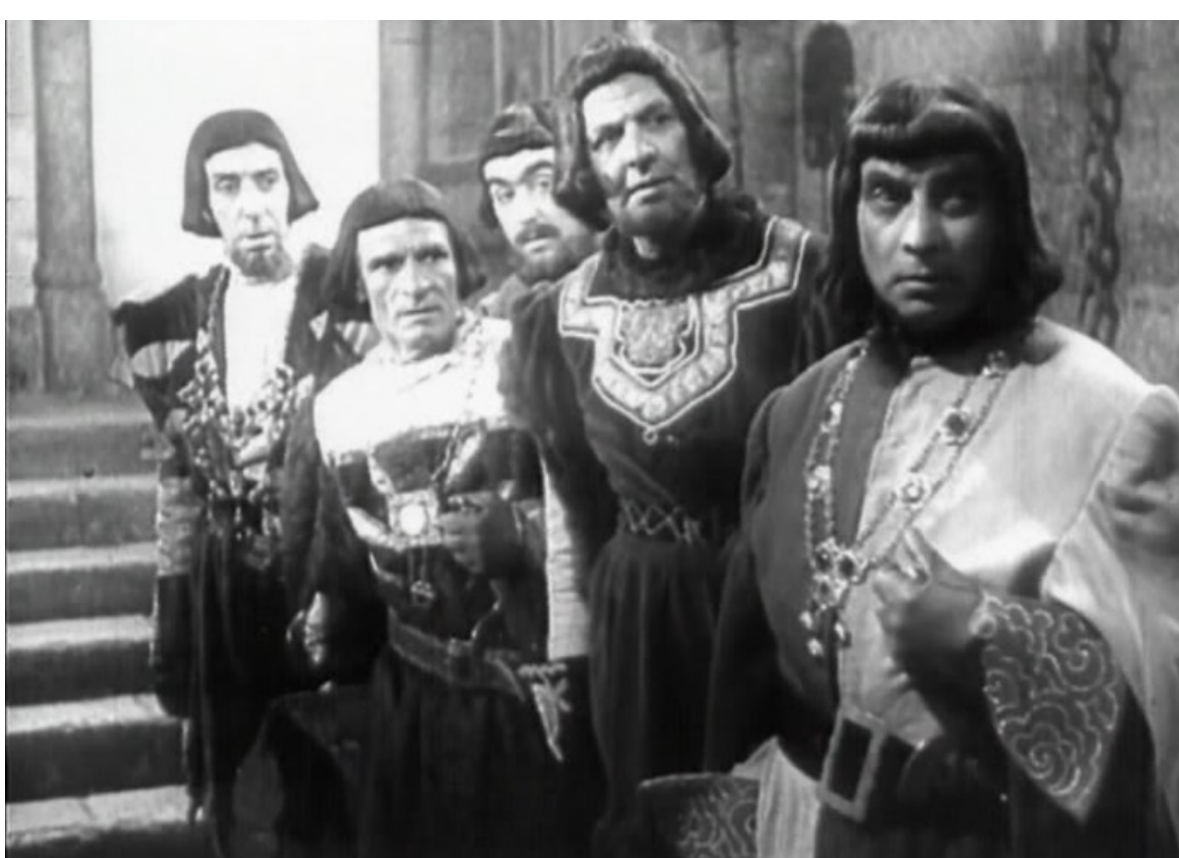

Fig. 1: Esa pareja feliz (1951), L.G. Berlanga y J.A. Bardem. Parodia al cine historicista

\section{ESA PAREJA FELIZ, EN EL CONTEXTO DISIDENTE DEL CINE ESPAÑOL} DE LOS 50

Esa pareja feliz, la ópera prima conjunta de Luis García Berlanga y Juan Antonio Bardem, es una película clave para comprender el cambio que se operó en el cine español de inicios de los 50 respecto a las propuestas fílmicas de postguerra. Junto a ella emergen otros filmes importantes para entender esta cuestión como Surcos (1951), de José Antonio Nieves Conde, y Bienvenido Mister Marshall, del propio Berlanga en solitario.

Berlanga y Bardem, a ese respecto, irrumpen como cineastas noveles que accedieron a la dirección de cine por medio de estudios reglados en el I.I.E.C., el Instituto de Investigaciones y Experiencias Cinematográficas de Madrid, a diferencia de otros directores de la época 
que solían llegar a la dirección por el rudo camino del meritoriaje. Berlanga consiguió el título, pero Bardem no llegó a finalizar los estudios. Sin embargo, ambos se erigieron en estandartes de una nueva época en el cine español de los años 50 y capitanearon la disidencia cinematográfica al adocenado séptimo arte que pervivía en España con la continuidad de los planteamientos de la década anterior. Y es que el cine de postguerra venía marcado por la autarquía económica, la austeridad de medios y el deseo de justificar la política de Franco y la victoria en la "Cruzada contra los rojos", a través de filmes historicistas que rememoraban algunas hazañas pretéritas de la Historia de España, siempre desde un punto de vista decimonónico muy relacionado con la literatura de la segunda mitad de este siglo y la pintura de historia. Filmes como el citado Locura de amor o Agustina de Aragón (1950), dirigidos ambos por Juan de Orduña, daban la espalda a las nuevas tendencias del cine europeo como el neorrealismo italiano, y mostraban una falsa puesta en escena de cartón piedra, unos diálogos imposibles, unas interpretaciones grandilocuentes y unos vestuarios y pelucas de regusto rancio.

Por el contrario, Esa pareja feliz, Surcos y Bienvenido Mister Marshall pretendían contar historias de gentes humildes como obreros, amas de casa, campesinos o inmigrantes. Estas historias cotidianas se enmarcaban en la triste realidad de la dictadura y la postguerra. La joven pareja idealista que vive realquilada en el Madrid de Esa pareja feliz (Fig. 2), o la ingenua familia de inmigrantes rurales recién llegados a la capital de Surcos, o los habitantes de un pequeño pueblo castellano al que van a visitar los americanos del Plan Marshall en Bienvenido Mister Marshall, son ejemplo claro de ello. Los referentes se acercaban al ya citado cine neorrealista italiano que se ponía de moda en todo Europa, aunque en el caso de Bardem y Berlanga, sin perder el costumbrismo hispano ni referentes más castizos como el sainete o la novela picaresca del Siglo de Oro, visible en Esa pareja feliz y Bienvenido Mister Marshall. No se pueden olvidar tampoco otros géneros más internacionales como el film-noir francés y norteamericano, presentes claramente en Surcos.

Para cambiar el adocenado panorama cinematográfico español de finales de los 40 es fundamental la irrupción en escena en 1947 del ya citado I.I.E.C., el Instituto de Investigaciones y Experiencias Cinematográficas, por cuyas aulas pasaron jóvenes estudiantes de dirección, producción, guion, fotografía o montaje no maleados por el meritoriaje ni por los vicios y rutinas del oficio cinematográfico. Este hecho propiciaba que estos nuevos realizadores tuvieran ideas más renovadoras, que estuvieran ideológicamente más cercanos a los perdedores de la Guerra Civil, y que optaran por nuevas narrativas y lenguajes que comenzaban a vislumbrar una nueva esperanza en el cine español. Entre otros cineastas salidos del I.I.E.C. nos encontramos, aparte de con Berlanga y con

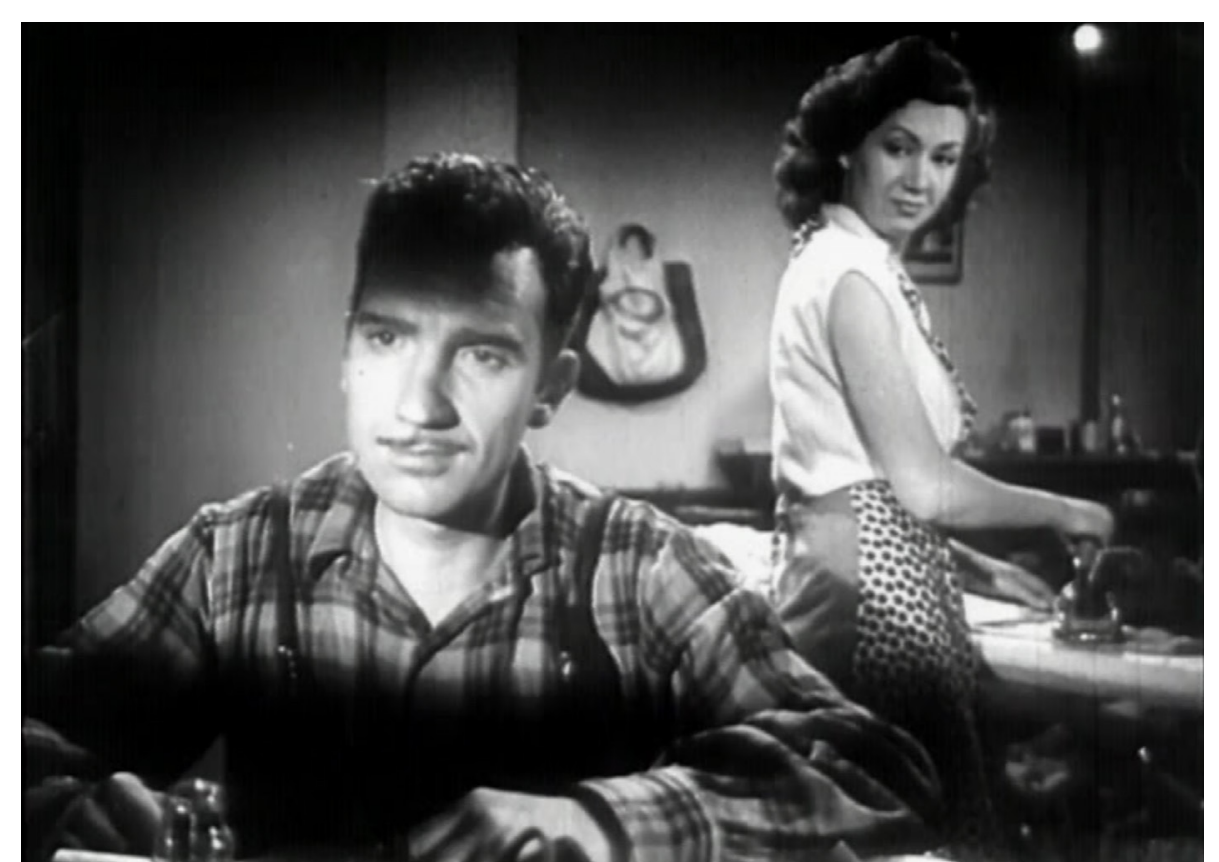

2: Esa pareja feliz (1951), L.G. Berlanga y J.A. Bardem. La humilde pareja protagonista

Bardem, con Ricardo Muñoz Suay, Florentino Soria, Eduardo Ducay, Paulino Garagorri y José Gutiérrez Maesso. Algunos de ellos, además, se embarcaron en la creación de una pequeña productora independiente: Industrias Cinematográficas Altamira, que tiene más valor histórico, pasados los años, por haber sacado adelante la película que nos atañe, que valor real, al haber llevado a cabo muy pocos proyectos hasta su desaparición ${ }^{4}$. Hay que

4 Industrias Cinematográficas Altamira es fundada por los egresados del I.I.E.C. citados en el texto más

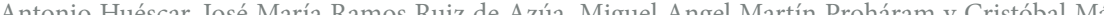
a quez Labajo A pear de intre los que destaca, aparte de Esa pareja feliz y Día tras día (1951), Familia provisional (1955), de Francisco Rovira Beleta con guion de Berlanga. Más información en RIAMBAU, E., y TORREIRO, C.: Productores en el cine español. Madrid, Cátedra, Filmoteca Española, 2008, p. 451. 
citar también la irrupción de UNINCI, la productora que llevó a cabo dos de los títulos más emblemáticos del cine español: Bienvenido Mister Marshall, de Luis García Berlanga y Viridiana (1962), de Luis Buñuel. También nos encontramos con un cineasta procedente del falangismo desencantado, en los nuevos tiempos en que Franco se apoya más en los tecnócratas, que es José Antonio Nieves Conde, que lleva a cabo estimables filmes críticos con la situación de España en los 50 como la ya citada Surcos o El inquilino (1957). Otro cineasta a tener en cuenta es el polifacético Fernando Fernán-Gómez, actor protagonista en Esa pareja feliz, y director de obras insólitas e inclasificables como El extraño viaje (1964), pero heredero del filme que nos ocupa en títulos como La vida por delante (1958) y su continuación La vida alrededor (1959). No olvidamos la irrupción a finales de la década del mejor guionista del cine español, Rafael Azcona, quien escribe las magistrales El pisito (1959), y El cochecito (1960) y quien comienza a trabajar con Berlanga en el mediometraje televisivo Se vende un tranvía $(1959)^{6}$. También hay que citar al director de estos dos filmes, el italiano Marco Ferreri, en solitario en el segundo y con Isidoro Martínez Ferry en el primero.

El otro hito fundamental que apoya la disidencia cinematográfica del cine español de los años 50 son las Conversaciones Cinematográficas de Salamanca celebradas en la ciudad castellana en 1955 y promovidas, entre otros, por Bardem, en las que se reunieron todos los estamentos del cine español para analizar los males que aquejaban al séptimo arte patrio y para intentar buscar soluciones que lo pudieran sacar de su precaria situación. Las conclusiones de este encuentro se resumen en el famoso pentagrama de Bardem que decía lo siguiente: "El cine español es: políticamente ineficaz, socialmente falso, intelectualmente ínfimo, estéticamente nulo e industrialmente raquítico". De estas cinco conclusiones no estamos de acuerdo con la última porque, a pesar de proliferar el minifundismo en producción, había algunas empresas como Cifesa, Ifisa o Suevia Films que realizaban gran cantidad de producciones y daban empleo a muchos profesionales del séptimo arte. Lo que si que dejaron las Conversaciones de Salamanca fue un germen para que a inicios de los 60 irrumpiera con fuerza una nueva manera de hacer cine vinculada a la Escuela Oficial de Cine, E.O.C., heredera del I.I.E.C. donde una nueva generación de cineastas abanderó el N.C.E., Nuevo Cine Español. La punta de lanza de este nuevo cine se llama Carlos Saura que a finales de la década realiza Los golfos (1959), verdadera tarjeta de presentación de la nueva modernidad en el cine español de la década siguiente.

El cine ineficaz, falso, ínfimo, nulo y raquítico al que se referían las conclusiones de las Conversaciones era un cine de género con gran arraigo popular y buenos resultados de taquilla en muchas ocasiones. Cineastas procedentes de la década anterior como José Luis Sáenz de Heredia, Rafael Gil o Antonio Román, conocían a la perfección el oficio y hacían películas muy dignas desde el punto de vista técnico, tocando todos los géneros: religioso, folklórico, cine de niños, comedia costumbrista... Ejemplos de lo que acabamos de comentar son: Historias de la radio (1954), comedia urbana de José Luis Sáenz de Heredia, La guerra de Dios (1953), filme de cariz religioso de Rafael Gil, o Los clarines del miedo (1958), obra taurina de Antonio Román. También, el citado Juan de Orduña lleva a cabo filmes finales del historicismo y grandes éxitos populares como Alba de América (1951), canto de cisne del "cine historicista de pelucón". Otros cineastas no alejados del Régimen pero más inclasificables como Edgar Neville, rara avis que desarrolla filmes magníficos en los 40 y que en los 50 sigue al pie del cañón con pequeñas joyas como El último caballo (1950), o Manuel Mur Oti, más pedante y efectista que conciso y trascendente, como demuestra en Cielo negro (1951), acompañan a Ana Mariscal, autora de la estimulante Segundo López, aventurero urbano (1953), o a Ladislao Vajda, director de Mi tío Jacinto (1956), la mejor obra de la trilogía del actor infantil Pablito Calvo. Por su parte, Antonio del Amo, tras su flirteo con el cine renovador de Industrias Cinematográficas Altamira, lanza la carrera del ilustre niño cantor Joselito, a quien dirige en El pequeño ruiseñor (1956). No olvidamos a José María Forqué que lleva a cabo, entre otros, en esta década, el film de bandoleros Amanecer en puerta oscura (1957), ni tampoco a Pedro Lazaga quien dirige, entre otras, la comedia rosa Las muchachas de azul (1957). Todos ellos tienen alguna película magnífica dentro de unas carreras con altibajos, pero con gran dominio del medio cinematográfico. El género policiaco también tiene un impulso, principalmente en Barcelona, gracias a cineastas como el inclasificable Ignacio F. Iquino, que rueda obras tan significativas como Brigada criminal (1950).

5 Sobre UNINCI es fundamental el siguiente libro: SALVADOR MARAÑón, A.: De Bienvenido Mister Marshall a Viridiana. Historia de Uninci: una productora cinematográfica española bajo el franquismo. Madrid, Egeda y 8 y medio, 2006.

6 Azcona fue coguionista de todos los filmes de Berlanga desde Se vende un tranvía (1959) hasta Moros $y$ cristianos (1988) 


\section{BARDEM Y BERLANGA EN LOS 50}

Bardem y Berlanga se conocieron, como ya se ha comentado, estudiando en el I.I.E.C. y aparte de hacer buenas migas, filmaron algunas de las prácticas de la escuela juntos. Paseo por una guerra antigua (1948), obra que presenta un recorrido por un antiguo campo de batalla de la Guerra Civil reconvertido en estadio de la Ciudad Universitaria de Madrid, fue realizada por los dos cineastas que nos ocupan más Florentino Soria y Agustín Navarro. El circo (1949), documental que nos muestra las rutinas de la instalación de un circo en las afueras de Madrid, por su parte, fue dirigida también por el tandem de Esa pareja feliz, que también trabajó en equipo en la escritura de varios guiones como Cerco de ira (1949), melodrama rural con apuntes sociológicos ambientado en Ibiza, lugar en que no habían estado ninguno de los guionistas, y que fue una película inacabada escrita para el profesor del I.I.E.C. y maestro de ambos Carlos Serrano de Osma. El guion más exitoso escrito por el madrileño y el valenciano fue el de Bienvenido Mister Marshall, rematado en diálogos por Miguel Mihura y dirigido, finalmente, en 1952 por Berlanga en solitario. Otro guion de ambos autores finalmente filmado fue La huida (1956), que contaba la historia de un hombre que huye y que acaba en un pueblo abandonado. Esta película fue realizada posteriormente por Antonio Isasi-Isasmendi ${ }^{7}$. Otro guion que llevaron a cabo en conjunto Bardem y Berlanga, basándose en una idea de Edgar Neville y con la colaboración de José Luis Colina, fue el de Novio a la vista (1953), dirigida de nuevo por Berlanga en solitario. Por su parte, el madrileño y el valenciano también escribieron conjuntamente algunos otros guiones que no llegaron a rodarse como El hombre vestido de negro (1950), localizado en las Fallas de Valencia, con una reflexión sobre la justicia y un inocente perseguido injustamente ${ }^{8}$, o Bohemios (1953), un guion que no se convierte finalmente en película y que era una adaptación de una zarzuela de Amadeo Vives.

Repasando someramente la filmografía en solitario de ambos directores en la década de los 50, tras su estreno en 1951 con Esa pareja feliz, hay que destacar que tanto Bardem como Berlanga, fueron los dos cineastas más significativos del período que nos interesa, ya que lograron trascender con sus obras, seleccionadas en los más importantes festivales cinematográficos internacionales, siendo hoy día consideradas como algunas de las películas más importantes del cine español de todos los tiempos.

SOJO GIL, K.: El verdugo. Guía para ver y analizar. Valencia, Nau Llibres, 2016, p. 138

CERÓN GÓMEZ, J.F.: El cine de Juan Antonio Bardem. Murcia, Universidad de Murcia y Primavera cinematográfica de Lorca. 1998. p. 37
Comenzando con Berlanga, tras Esa pareja feliz, filma la ya citada Bienvenido Mister Marshall en 1952 para la ya mencionada productora UNINCI. La intención principal de la empresa fue que la película fuese dirigida de nuevo por ambos, pero desavenencias de Bardem con la productora, provocaron que Berlanga fuera finalmente el único director de la cinta. La película, que narra la historia de los habitantes de un pequeño pueblo castellano que va a ser visitado por una delegación estadounidense del Plan Marshall, logra un éxito en taquilla y crítico sin precedentes y consigue una gran distribución internacional gracias a su paso por el Festival de cine de Cannes y a los dos premios que consigue en la ciudad de la Costa Azul: Mejor película de humor y mención especial de la FIPRESCI al guion de Berlanga, Bardem y Mihura. En Bienvenido Mister Marshall y Esa pareja feliz hay muchas coincidencias: el tono cómico costumbrista sainetesco berlanguiano, la alusión al regeneracionismo más bardeniano, el protagonismo en colectivos sociales humildes, la parodia y crítica al cine historicista...

Novio a la vista, la siguiente obra de Berlanga, de 1953, también cuenta, como ya se ha comentado anteriormente, con Bardem como guionista. El filme rompe con la línea marcada por los dos anteriores del valenciano al no proceder la idea original de su propio ingenio, ni del de Bardem, sino del de Edgar Neville. Producida por Benito Perojo y ambientada en los felices años 20, retrata el verano burgués de un pueblo mediterráneo y los devaneos amorosos de dos adolescentes, un poco en la línea del Jacques Tati de Les vacances de Mr. Hulot (Las vacaciones de Mr. Hulot, 1953).

Por su parte, Calabuch (1956) fue filmada tres años más tarde por el valenciano que tuvo que abandonar algunos proyectos que no salieron adelante por diversas razones. Tampoco la idea original partía del intelecto del levantino, sino de su compañero en el I.I.E.C. Leonardo Martín. Coproducida con Italia y con un reparto internacional encabezado por el norteamericano Edmund Gwenn y los italianos Valentina Cortese y Franco Fabrizzi, el filme narra la historia de un sabio atómico que busca una Arcadia feliz que le aleje del peligro propio de la Guerra Fría al que contribuye él fabricando bombas, y lo encuentra en Calabuch, un pequeño pueblo mediterráneo en que parece que no pasa el tiempo. La obra fue criticada como amable y ternurista, quizás por la intervención en el guion de Ennio Flaiano9. Sin embargo tiene momentos memorables como los protagonizados por un entrañable torero itinerante (José Luis Ozores) que trata a su vaquilla como si fuese su hija (Fig. 3)

9 Ennio Flaiano, guionista habitual de Fellini y otros grandes del cine italiano de la época, repetiría con Berlanga en el guion de El verdugo (1963), también coproducción con Italia, al igual que Calabuch. 


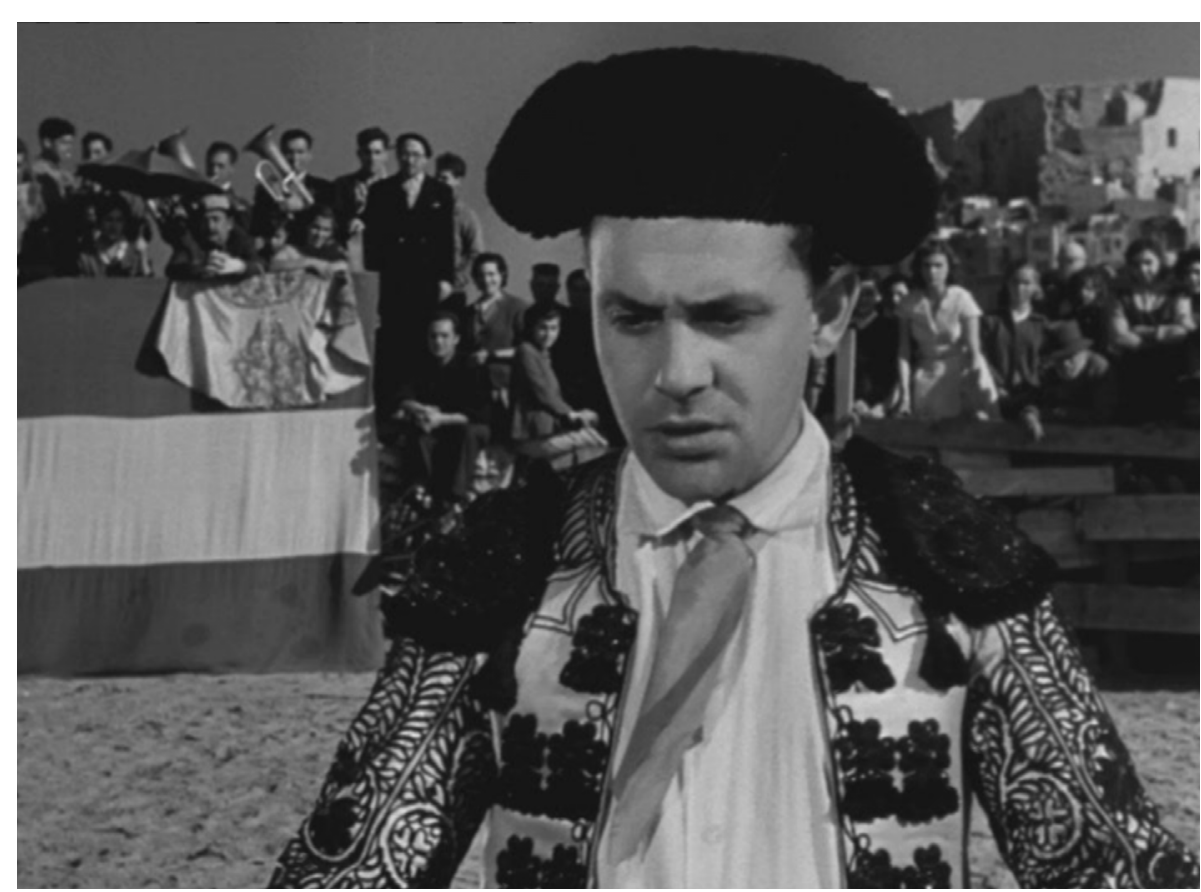

ig. 3: Calabuch (1956), L.G. Berlanga. El torero, personaje encarnado por José Luis Ozores

Un año más tarde llega otra coproducción con Italia, Los jueves milagro, película mutilada y modificada cruelmente por la censura, ya que su trama se centra en el engaño que las fuerzas vivas de un pueblo llevan a cabo estafando a la gente con la falsa aparición milagrosa de un peculiar San Dimas (José Isbert), y el deseo de reactivar el turismo en el abandonado balneario local siguiendo las modas de Lourdes o Fátima. Obviamente, la sátira antirreligiosa es fantástica en la primera parte de la película, con algunas de las mejores secuencias de toda la filmografía de Berlanga. Desgraciadamente, la actuación de la censura y de su representante con esta película, el padre Garau, transforma un filme antológico en una película lamentable finalizada por el director catalán Jorge Grau, en la que la aparición del verdadero San Dimas, encarnado por el apuesto actor estadounidense Richard Basehart, articula que el agua regeneracionista de los pantanos de Franco obre el milagro que irónicamente saque a España de la sequía ${ }^{10}$
La última obra de Berlanga de la década, Se vende un tranvía, es diferente a las anteriores por varios motivos. En primer lugar, se trata de la primera película de la etapa dorada de Berlanga que es aquella que se desarrolla entre 1959 y 1963 y se compone de este filme, de sus dos mejores obras Plácido (1961) y El verdugo (1963), y del episodio del filme colectivo Las cuatro verdades (1962), titulado La muerte y el leñador. En segundo lugar porque comienza su fecunda colaboración con Rafael Azcona y por último, por tratarse de un episodio piloto para una serie televisiva sobre los timos, en que unos estafadores quieren vender un tranvía a un paleto llegado a Madrid, y que fue codirigida por Juan Estelrich ${ }^{11}$.

Por su parte, la carrera de Juan Antonio Bardem en la década de los 50 no tiene nada que envidiar a la de Berlanga. En este período, el madrileño dirige tres de sus mejores películas Cómicos (1954), Muerte de un ciclista (1955) y Calle Mayor (1956), además de la comedia Felices pascuas (1954), el drama rural La venganza (1959) y la obra valleinclanesca Sonatas (1959). Comenzando por las tres primeras, en todas ellas se ve el marcado carácter político, reivindicativo, regeneracionista desencantado y comunista en la clandestinidad propio de la obra inicial de Bardem. Cómicos cuenta las vicisitudes de una compañía teatral que recorre teatros de ciudades de provincias de la España gris de la época y muestra el aburrimiento de los viajes y las aspiraciones de la protagonista Ana Ruiz (Christian Galvé) por prosperar en una profesión que Bardem conocía muy bien por ser familia de artistas. La secuencia inicial en el vagón del tren en que se presenta con voz en off al elenco de la compañía es absolutamente magistral. La película fue seleccionada a concurso en el Festival de Cannes.

Muerte de un ciclista plantea muchas incognitas. Con su impactante comienzo en que una pareja adultera atropella a un obrero que va en bicicleta y no dan parte a la policía, presenta una voraz crítica contra las clases acomodadas, un retrato desolador que nos muestra una España dividida, unas clases humildes que viven fatal, unas huelgas estudiantiles que muestran el inconformismo de la juventud de la época, y una crítica a la hipocresía de las clases burguesas del momento. En este caso, el filme si que triunfó a nivel internacional ganado el Premio de la crítica en Cannes (Fig. 4).

10 Esta cuestión se aborda en: SOJO GIL, K. "La censura en el cine español del franquismo. El caso de Los jueves milagro (1957), de Berlanga", en GUEREÑA, J.L. y ZAPATA, M.: Censures et manipulations dans les mondes ibérique et latino-américain, Tours, PUFR, 2013, pp. 175-192.

11 SOJO GIL, K.: "Se vende un tranvía (1959), o el comienzo de la época dorada de Luis García Berlanga", Cuadernos Cinematográficos. Vol. 10, Universidad de Valladolid, 1999, pp. 37-42. 


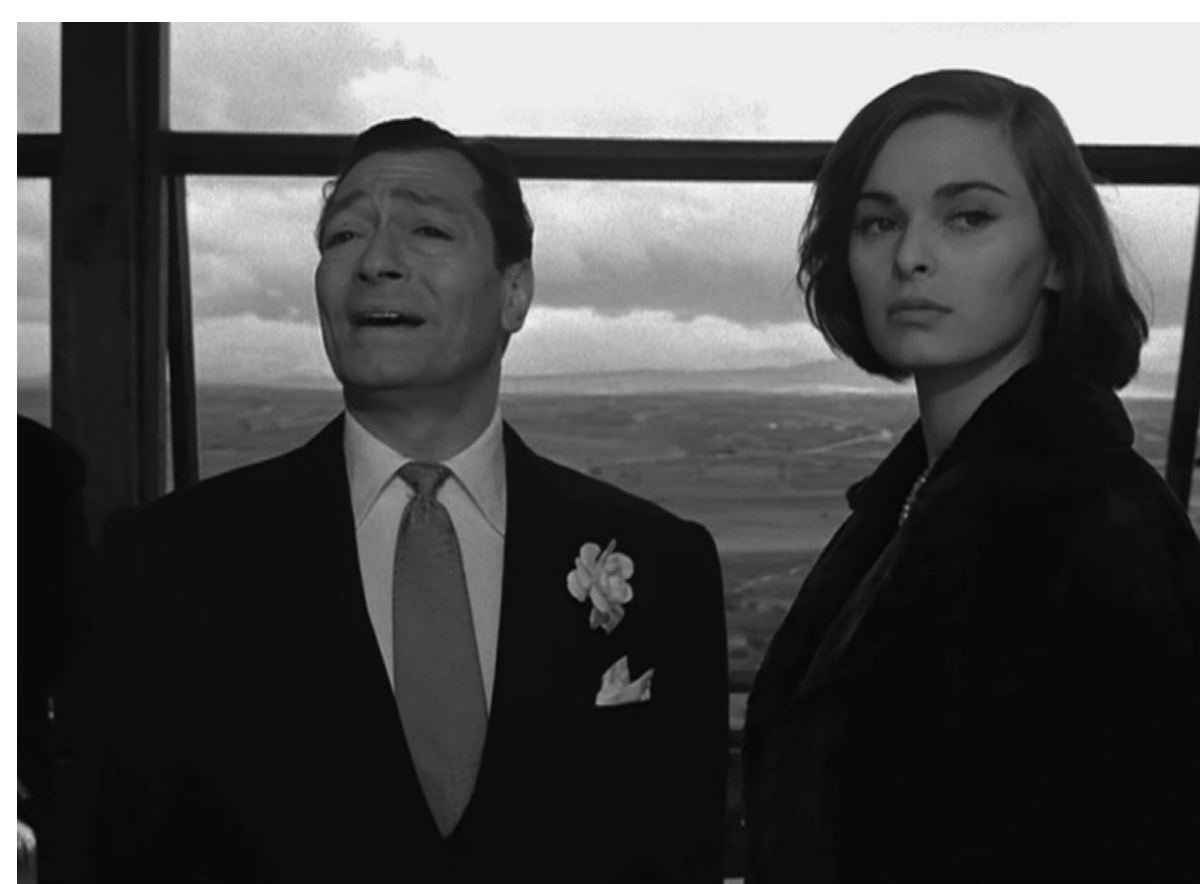

Fig. 4: Muerte de un ciclista (1955), J.A. Bardem. Carlos Casaravilla y Lucía Bosé

Por su parte, en Calle Mayor se nos narra de nuevo el aburrimiento de la ciudad levítica de provincias heredera de la Vetusta de La Regenta, de Clarín, y, por medio de otra protagonista femenina, como en Cómicos, se nos habla de las dificultades de las mujeres de mediana edad en el paisaje urbano de la época. El cruel engaño de un grupo de señoritos de casino a una solterona basado en La señorita de Trevélez, de Carlos Arniches, presenta un panorama desolador en la onda de la novela de Carmen Martín Gaite Entre visillos, alejado de la comicidad del sainete y más cercano al drama con escenas impactantes como la del final de la película que sume en tristeza y desolación a Isabel, la protagonista magníficamente interpretada por Betsy Blair y hace relexionar al espectador ${ }^{12}$.

12 SOJO GIL, K.: "Imagen translucida de la ciudad provinciana franquista a través del plano final de Calle Mayor (1956), de Juan Antonio Bardem", en PEYRAGA, P., GAUTREAU, M., PEÑA, C y SOJO GIL, K. La imagen translúcida en los mundos hispánicos. Villeurbanne, Orbis Tertius, 2016, pp. 439-457.
Sin llegar al nivel de los anteriores, los otros tres filmes de Bardem de la década son estimables y deben ser comentados también por diversas razones. Felices pascuas recuerda un poco al costumbrismo de Esa pareja feliz y se asemeja más a la comicidad de Berlanga que a la amargura de Bardem. La premisa es buena. Un matrimonio humilde gana un corderito en una rifa y deciden comérselo en Nochebuena, pero les da pena matarlo porque los hijos se han encariñado con el animal. Por su parte, La venganza es un desaforado drama rural sin concesiones ambientado en el mundo de los jornaleros temporeros que recorren campos para ganarse el sustento. Con un trasfondo de una injusta estancia en prisión del protagonista y sus deseos de venganza por el crimen que supuestamente no cometió, el filme transita por terrenos desiguales destacando la eficacia de su reparto, especialmente Carmen Sevilla, Francisco Rabal y el italiano Raf Vallone. Por último, Sonatas, coproducida con México, reproduce las aventuras valleinclanescas del Marqués de Bradomín con María Felix y Francisco Rabal, de nuevo, en los papeles protagonistas.

\section{GÉNESIS Y REPERCUSIÓN DE ESA PAREJA FELIZ}

Como ya se ha comentado anteriormente, el origen de Esa pareja feliz hay que unirlo al germen generado por los estudiantes del Instituto de Investigaciones y Experiencias Cinematográficas, I.I.E.C., Luis García Berlanga y Juan Antonio Bardem. El primer tratamiento que recibe el guion adopta unos tintes dramático-sentimentales, más cercanos, sin duda alguna, al universo posterior de Juan Antonio Bardem, que al propio de Berlanga. La película es protagonizada por Fernando Fernán-Gómez, actor que acababa de encabezar el reparto de la exitosa Balarrasa (1951), de José Antonio Nieves Conde y que comenzaba a tener un estatus en el cine español que podía valer a los nuevos realizadores para vender, distribuir y estrenar la película. La protagonista femenina elegida es, por su parte, la actriz barcelonesa Elvira Quintillá, más prolífica en teatro y esposa del actor teatral José María Rodero, que aparece en un pequeño papel en el filme.

La película es producida por la ya citada pequeña productora Industrias Cinematográficas Altamira S.L., que merced al estreno tardío y escasa repercusión de Esa pareja feliz y al fracaso de Día tras día, de Antonio del Amo, durará hasta 1955 siguiendo en sus últimas producciones una línea más conformista que la que se presuponía con su creación ${ }^{13}$.

13 MONTERDE, J.E. "El cine de la autarquía". Dentro de GUBERN, R.: Historia del cine español. Madrid, Cátedra, 2010, p. 260. 
La filmación de Esa pareja feliz pasó por innumerables vicisitudes. Bardem y Berlanga trabajaban en el guion en primavera de 1950. Se pidió un permiso para comenzar en agosto de ese año, pero el proyecto quedó pospuesto por la productora que se centraba en la citada Día tras día ${ }^{14}$. El rodaje arrancaba el 16 de abril de 1951 para finalizar el 6 de octubre del mismo año. El nuevo tratamiento del guion originó una reducción de 200.000 pesetas del presupuesto inicial. El lapso de tiempo transcurrido entre la anterior versión de guion y la nueva provoca un giro del mismo hacia el humor y una dulcificación, en cierto modo de las intenciones iniciales ${ }^{15}$. Por otro lado, las condiciones de rodaje fueron bastante austeras y penosas y en ese sentido en la secuencia inicial que parodia un rodaje de un filme historicista de "fazaña" de los años 40, nos presenta los problemas habituales en una filmación cinematográfica de la época. El actor que encarna al director de cine historicista en la citada escena suelta una sintomática frase que lo corrobora: "iQué barbaridad! ¿Así como se puede hacer cine?”"16 (Fig. 5). Y es que los conflictos se sucedían en la propia filmación ya que había problemas con el suministro eléctrico y con la escasez de película virgen ${ }^{17}$. Las tensiones entre los socios capitalistas y los promotores de la empresa dificultaron un rodaje que se pudo finalizar por la aportación de un particular que invirtió 300.000 pesetas en la película $^{18}$. La censura no se cebó especialmente con la obra resultante, a diferencia de lo que sucedería con otros filmes de Bardem y Berlanga, cuidando las efusiones amorosas del matrimonio y la secuencia de la comisaría ${ }^{19}$

En lo que concierne a la repercusión de la obra, Esa pareja feliz fue estrenada el 31 de agosto de 1953, cuatro meses más tarde de la premiere de Bienvenido Mister Marshall. Fue una película que no tuvo suerte en taquilla, que salió con una distribución discreta y más bien

14 CERÓN GÓMEZ, J.F. op. cit., p. 79

15 Ibid. p. 80. Los cambios más reseñables frente a la primera versión del guion eran: la profesión de Carmen, que trabajaba en unos grandes almacenes, la aparición de unos personajes secundarios dueños de una mercería castiza, la pérdida de un hijo por parte de la pareja que dotaba un trasfondo dramático a la acción y un final esperanzador en que, tras las celebraciones de la "pareja feliz", Juan y Carmen reciben la noticia que esperan un hijo.

16 Erróneamente, Juan Hernández Les y Manuel Hidalgo han atribuido esa frase al protagonista del filme, Juan (Fernando Fernán Gomez). Basta ver la película para observar que dicha frase sale de la boca de director de la ficticia película filmada. La referencia exacta a este lapsus es: HERNANDEZ LES, J. e HIDALGO, M.: El último austro-húngaro. Conversaciones con Berlanga. Barcelona, Anagrama, 1980, p. 28

17 HEREDERO, C. F.: Las huellas del tiempo. Cine español. 1951-1961. Madrid, Filmoteca española y Filmoteca de la Generalitat Valenciana, 1994, p. 310.

18 GÓMEZ RUFO, A.: Berlanga. Contra el poder y la gloria. Escenas de una vida. Madrid, Temas de hoy, 1990, p. 236

19 CERÓN GÓMEZ, J.F.: op. cit., p. 81.

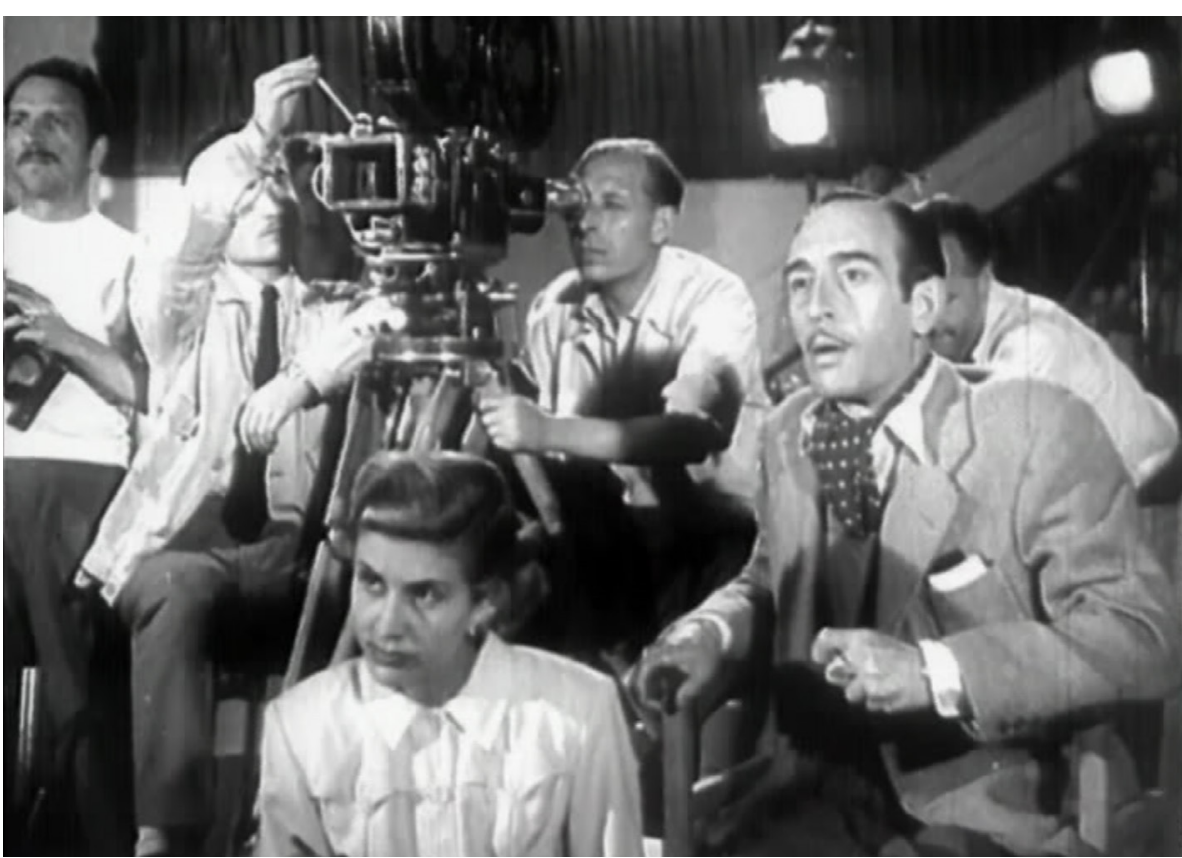

5: Esa pareja feliz (1951), L.G. Berlanga y J.A. Bardem. Dificultades para hacer cine en España

de tapadillo y que tuvo algo de repercusión gracias al éxito de Bienvenido Mister Marshall. Y eso que se efectuó un pase privado de la película para críticos y profesionales en el Cine Pompeya de Madrid el 12 de octubre de 1951, recibiendo una acogida entusiasta por parte del sector del cine que veía en la cinta una propuesta novedosa, pero que no sirvió para que fuera distribuida en salas en ese momento ${ }^{20}$. Problemas con la administración demoraron el estreno de la película, comprada por la modesta distribuidora Iris Films que estrenó el filme, como ya hemos dicho, gracias al éxito logrado por Berlanga con Bienvenido Mister Marshall. La película fue vista por 8.136 espectadores logrando una recaudación de 222.108 pesetas $^{21}$

20 GUBERN, R.: “Esa pareja feliz", en PÉREZ PERUCHA, J.: Antología crítica del cine español (1906-1995). Madrid, Cátedra y Filmoteca Española, 1997. p. 305. 21 SOJO GIL, K.: Americanos, op. cit., p. 346 
La administración no ayudó mucho a la película calificándola de $2^{\mathrm{a}} \mathrm{y}$ tan sólo elevada a $1^{\text {a }}$ cuando José María García Escudero llegó a la Dirección General de Cinematografía, obteniendo tan sólo una única licencia de importación y doblaje. Según Carlos F. Heredero, esta penosa situación dejó a la productora Industrias Cinematográficas Altamira en crisis ${ }^{22}$. En cualquier caso, la película no tuvo el recorrido que merecía ni la repercusión que, años después, la ha dejado en su sitio en términos cualitativos. Al menos, el filme fue estrenado en Francia y obtuvo dos premios: Premio Jimeno revelación del CEC a la Dirección Novel a Berlanga y Bardem. 1951, y Mención de Honor en los III Encuentros Internacionales de Cine para la Juventud. Cannes, julio de $1952^{23}$

Tras el pase privado para profesionales del Cine Pompeya, la crítica fue favorable en un principio. Juan Francisco Cerón recoge algunas reseñas positivas de la película como la que Pedro Recio hacía en la revista Ambiente:

"Es elogiable que estos personajes pertenezcan a un mundo real: porque son dos obreros, no personajes de una falsa clase media o de un gran mundo que luego siempre resulta un mundo demasiado pequeño"24.

Los directores Bardem y Berlanga eran también vanagloriados en otra publicación, Triunfo:

"Un dúo que va a dar más de un disgusto a los consolidados prestigios, y qué si les dejan, -que ya procurarán entre unos y otros no dejarles-, se van a subir a las barbas de mucha gente"25.

A pesar del paso por taquilla con más pena que gloria de Esa pareja feliz, a finales de agosto de 1953, la crítica tampoco fue mala en general, aunque venía mediatizada por el éxito en Cannes de Bienvenido Míster Marshall. En el diario El Alcázar podían leerse las siguientes palabras:

"Es, en fin, la que hemos visto, una buena película, que se suma a este renacimiento que, al parecer, está llegando al cine español por obra y gracia de la juventud"26.

22 HEREDERO, C. F.: op. cit., p. 310

3 SOJO GIL, K.: Americanos.... op. cit., p. 346.

Ambiente. 20/10/1951. p. 186. Tomado de CERÓN GÓMEZ, J.F.: op. cit., p. 92.

Ibid. En este caso la referencia original tomada por Cerón es: Triunfo, 17/10/1951.

26 Ibid. p.94. Referencia original: OLANO, A.D., “Esa pareja feliz, película feliz”, El Alcázar, 2/9/1953. p. 4

\section{REFERENTES CINEMATOGRÁFICOS DE ESA PAREJA FELIZ}

Bardem y Berlanga, a finales de los años 40, eran estudiantes de cine y vivían el séptimo arte de una manera muy apasionada. La película que nos ocupa rezuma cinefilia y continuas alusiones a esta disciplina artística. De ese modo, el protagonista de la cinta trabaja como eléctrico en unos estudios de cine en que se rueda una película historicista o acude a una sala a ver con su esposa Love Affair (Tú y yo, 1939), de Leo McCarey, siendo, de este modo, los referentes cinematográficos para escribir el guion y filmar la película, variados y abundantes, como han reconocido los directores en varias ocasiones ${ }^{27}$. En este caso, la inspiración recibida no fue solamente fílmica ya que en Esa pareja feliz se atisban rasgos procedentes de la literatura y concretamente del sainete costumbrista del escritor alicantino Carlos Arniches, quien puede ser considerado como un referente diáfano en el cine del primer Berlanga, así como en el Bardem de Calle Mayor ${ }^{28}$. Como comentábamos al inicio de esta publicación, se han citado en diversas ocasiones los referentes utilizados por Bardem y Berlanga para construir la película, pero no se han analizado, hasta el momento, los grados de relación entre estos modelos originales y Esa pareja feliz, siendo este uno de los objetivos principales que planteamos desde aquí. Comencemos con los referentes relativos al séptimo arte.

A nivel cinematográfico, algunas películas pueden ser consideradas claramente como modelos referenciales de este filme dramático-sentimental. Nos referimos a: Lonesome (Soledad, 1928), de Paul Fejos, Christmas in July (Navidades en julio, 1940), de Preston Sturges, Antoine et Antoinette (Se escapó la suerte, 1946), del director galo Jacques Becker, y From This Day Forward (De hoy en adelante, 1946), de John Berry ${ }^{29}$. También se observa cierta relación entre la película y los cines de Frank Capra y René Clair y no hay que olvidar la mano de Carlos Serrano de Osma, maestro en el I.I.E.C. de Bardem y Berlanga, sin dejar de lado la relación entre los artífices del filme y el neorrealismo italiano.

Soledad es una interesante película realizada en Estados Unidos por el director de origen húngaro Paul Fejos, cuando el cine mudo tocaba a su fin. Estéticamente recuerda bastante a Sunrise (Amanecer, 1927), de Murnau, sobre todo las escenas localizadas en la feria, y en

27 HERNANDEZ LES, J. e HIDALGO, M.: op.cit., pp. 30-31.

28 Aunque Calle Mayor opta por el drama y no por la comedia moralizante que suponía el texto original en el que se basaba la película que era La señorita de Trevélez. 29 CAÑEQUE, C., y GRAU, M.: op. cit., p. 186. 
la feroz tormenta que se desata en esta localización en ambas obras. Llama la atención que el filme de Fejos, al encontrarse en el paso del mudo al sonoro, cuenta con varias secuencias sonoras, algunas de ellas dentro del desarrollo de la historia de amor, donde escuchamos la voz de los personajes. La película narra la historia de un obrero y una telefonista, que, tras ver la publicidad de un parque de atracciones situado en Coney Island, acuden a este lugar y se conocen. Tras pasar un magnífico día de playa y disfrutar de las atracciones de la feria, son separados en la montaña rusa, y tras muchas vicisitudes, el hombre y la mujer descubren por casualidad que son vecinos, y unen sus vidas para siempre ${ }^{30}$. Entre las cosas que les ocurre hay un desmayo de la joven por un incidente en la atracción y un paso por comisaria del chico, que recuerda, por el tono paternalista del policía que le atiende, a la secuencia previa al desenlace de la película de Berlanga y Bardem. La suerte, el azar y la casualidad son cuestiones desarrolladas en la película estadounidense. La muchacha pierde un anillo en la playa y el muchacho lo encuentra entre los granos de arena, dando a entender que el encuentro casual producido por la pareja está metafóricamente representado por la insignificancia de los granos de arena en la inmensidad de la playa. La multitud que les rodea en el trabajo, en la feria, en el metro o en la playa simboliza la inmensidad de la cual emerge el encuentro fortuito que unirá sus vidas para siempre (Fig. 6). Las conexiones apreciadas entre Esa pareja feliz y el filme de Fejos son principalmente argumentales y temáticas, ya que hay un abismo entre la manera de narrar del húngaro y los directores españoles. Básicamente son las siguientes:

Los protagonistas de la película española también se conocen en un parque de atracciones, y allí se enamoran. En el filme norteamericano la pareja se refleja en espejos deformantes, cosa que sucede también en el español. La condición obrera de los personajes de Fejos, interpretados por Barbara Kent y Glenn Tyron, coincide con la de la obra de Bardem y Berlanga. En la película estadounidense, ella encarna a una telefonista y el a un trabajador de una fábrica, como ya se ha apuntado con anterioridad. Ambos viven en modestas habitaciones que recuerdan claramente a la vivienda de la película que nos atañe. La secuencia de la noria de Esa pareja feliz tiene su correspondencia con la de la montaña rusa de Soledad. En ambas pasa algo inesperado pero que finalmente acaba uniendo a las dos parejas.

Navidades en julio tiene quizás más que ver con Esa pareja feliz que el citado filme de Fejos. La película de Preston Sturges, un ejemplo canónico de screwball comedy, genero dominado a la perfección por el director norteamericano, influye de especial manera

30 ALSINA THEVENET, H.: Historia del cine americano /1. (1893-1930) Desde la creación al primer sonido. Barcelona, Laertes, 1993, pp. 67,138 y 144

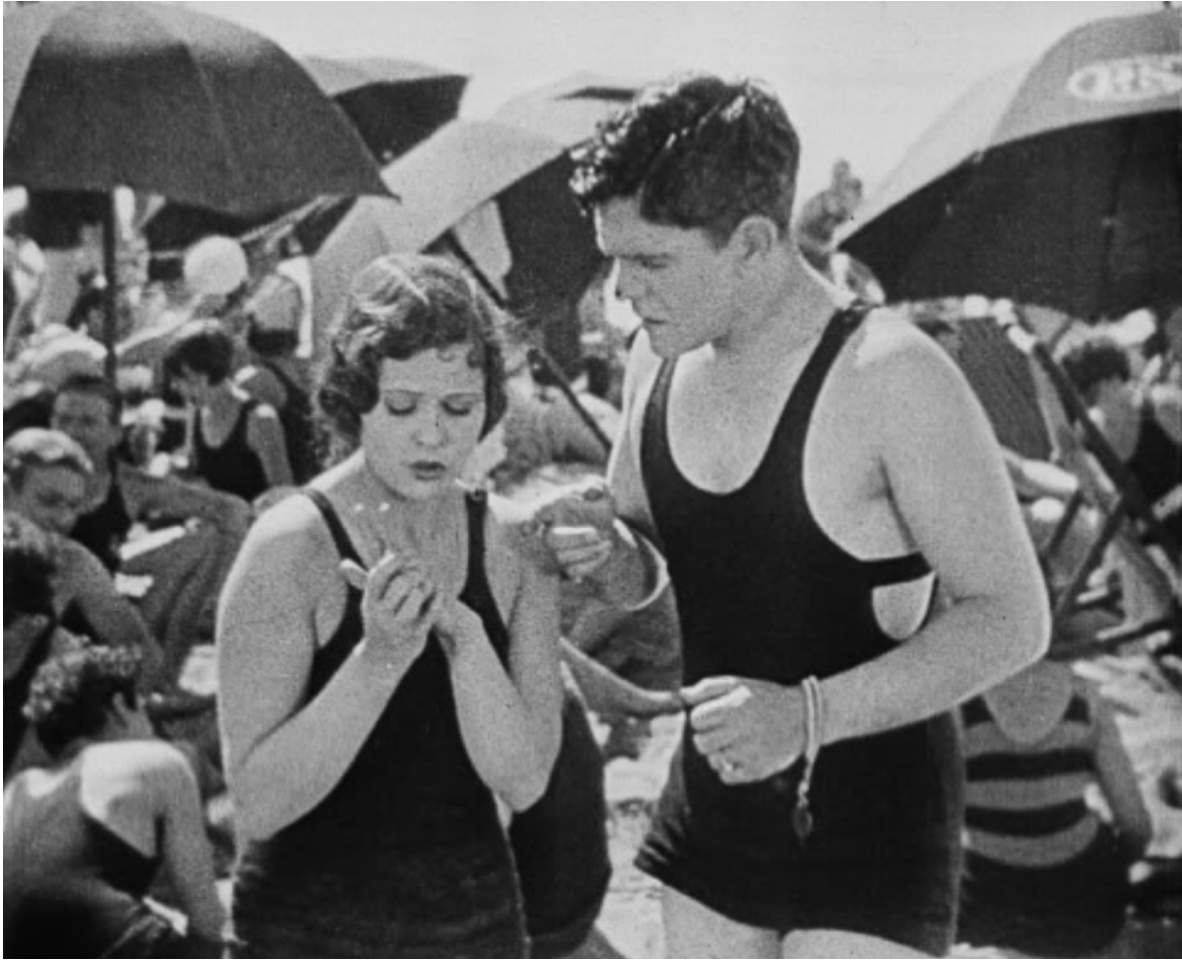

Fig. 6: Lonesome (Soledad, 1928), Paul Fejos. La joven (Barbara Kent) ha perdido su anillo en la playa

en Berlanga y Bardem en el modo de sátira social resuelto con un tono tragicómico que está presente en ambas obras ${ }^{31}$. La coincidencia más grande entre ambas películas es la presencia de un concurso, muy parecido al del Jabón Florit de la cinta española ${ }^{32}$, que en el caso del filme norteamericano lo propone la marca de café Maxford House Company. El protagonista de Navidades en julio, Jimmy MacDonald (Dick Powell) se cree ganador

31 El caso de Preston Sturges es digno de mención, ya que dentro del sistema de estudios del Hollywood de los años 30 y 40 no era frecuente que el director y el guionista de una película fueran la misma persona, ya que los guionistas profesionales eran contratados por las majors para escribir los filmes que eran encargados a los directores que normalmente no tenían que ver con los guionistas. Sturges, en el caso de 
del concurso a causa de un telegrama falso enviado por sus compañeros de trabajo para gastarle una broma en que figura que el incauto Jimmy ha ganado los 25.000 dólares del premio. Preso de la alegría desbordada, Jimmy hace compras increíbles, ante la sorpresa de su novia Betty (Ellen Drew). Obviamente, el chico no podrá pagar tantos regalos. En este caso, el personaje de Jimmy, aficionado a los sorteos y concursos, influye en el de Carmen del filme de Bardem y Berlanga. La "pareja feliz" de nuestra película disfruta de manera efímera de su inusual jornada festiva, ya que al día siguiente vuelve la rutina y nada cambia.

En la película de Sturges hay dos secuencias memorables. La primera, es la llegada de la pareja a su humilde barrio con las compras y la ruptura del sueño a causa de los empresarios que quieren echar por tierra las ilusiones de los jóvenes. Esta cuestión provoca un motín en toda regla de los vecinos de Jimmy y Betty (Fig. 7). La segunda secuencia es la que transcurre en la azotea en la que la pareja sueña con muchas cosas mientras escuchan por la radio el supuesto resultado del concurso. Esta secuencia, en que hay una azotea y una radio y muchos sueños, recuerdos y anhelos, es referenciada en Esa pareja feliz, para dar paso al flashback en que Carmen y Juan recuerdan como se conocieron. El estilo visual del Berlanga de esta película y posteriores, guardará más similitudes con el de Preston Sturges que el de Bardem. Algunos otros rasgos de la obra que nos ocupa que aparecen en Navidades en julio son la utilización de eslóganes publicitarios, sobre todo los relacionados con el concurso de café y que sirven de modelo para los ya repetidos: "a la felicidad por la electrónica" o "sean ustedes la pareja feliz del jabón Florit". No olvidamos el reparto de regalos que el incauto Jimmy hace a sus modestos vecinos, al igual que Juan y Carmen al final de Esa pareja feliz, o el recorrido por las tiendas de lujo que llevan a cabo los protagonistas del filme estadounidense, que recuerdan al itinerario seguido por los de la obra de Bardem y Berlanga. Tampoco hay que olvidar la frase que dice el protagonista de Navidades en julio: "la felicidad cuesta dinero", que aparece citada en el filme español Además, en la comedia de Sturges, a diferencia de la obra que nos ocupa, el final es feliz ya que, tras la confusión generada por el bromazo del telegrama, Jimmy gana realmente el premio del concurso y puede hacer realidad todos los sueños que se han ido atisbando a lo largo del filme.

Navidades en julio, escribió y dirigió la película, e hizo lo propio con más títulos. Interesante el apartado que sobre Preston Sturges se observa en ECHART, P. La comedia romántica del Hollywood de los años 30 y 40. Madrid, Cátedra, 2005, pp. 197-206.

32 En Esa pareja feliz, los protagonistas de la cinta son agraciados con el premio de un concurso otorgado por la marca comercial Jabón Florit, que consiste en pasar un día con todos los gastos pagados por la capital de España visitando lujosas tiendas, comiendo en restaurantes de postín y acudiendo a espectáculos musicales.

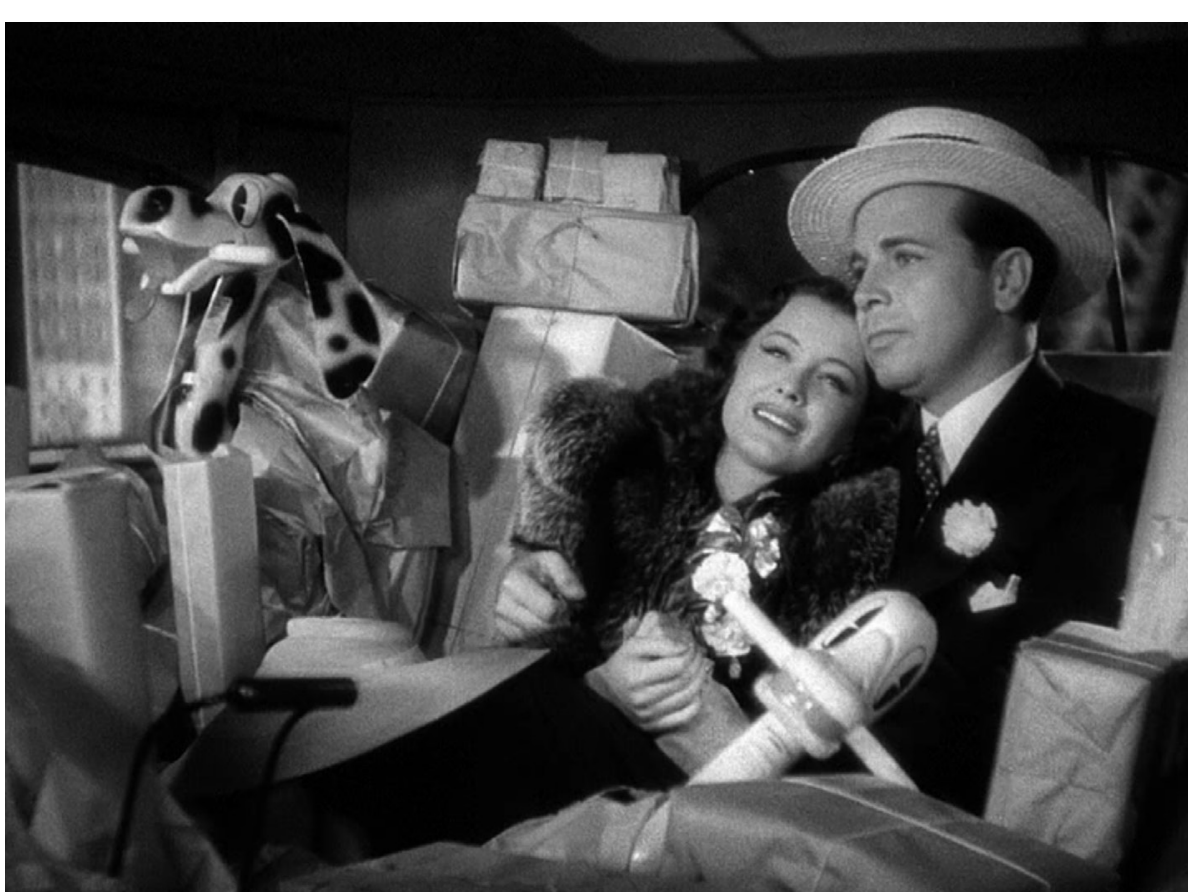

Christmas in July (Navidades en julio, 1940), de Preston Sturges. La pareja interpretada por Ellen Drew y Dick Powell, se dirige al barrio cargada de regalos

La influencia de Se escapó la suerte, del realizador francés Jacques Becker, a la película que nos ocupa, está más cercana al cine de Bardem, que al de Berlanga. Además, la cinta de Becker también guarda una estrecha relación con Navidades en julio y funciona como un paso medio entre esta obra y la que nos atañe. El filme francés en cuestión, realizado sólo cinco años antes del español, se relaciona claramente con el planteamiento general de Esa pareja feliz. Se escapó la suerte, primera película de Becker estrenada en España, transita también por mundos citados en referentes anteriores como la pareja humilde y el tema de la suerte o el azar por medio de un billete de lotería que puede cambiar la fortuna de los protagonistas, Antoine Moulin (Roger Pigaut) y su esposa Antoinette (Claire Maffei). 
Mientras el marido es empleado de imprenta y experimenta con aparatos de radio, la mujer trabaja en un fotomatón de unos grandes almacenes y cose en los ratos libres para sacarse un sobresueldo, al igual que Juan y Carmen en Esa pareja feliz ${ }^{33}$. De ese modo, el filme de Becker influye claramente en la ópera prima de Berlanga y Bardem por tres motivos principales:

El primero sería el modo en que el realizador galo nos presenta una visión realista y un tanto sarcástica de Francia en la convivencia posterior a la II Guerra Mundial. Los vecinos del modesto bloque en que viven Antoine y Antoinette son como una familia y se ayudan, como sucede con los de Esa pareja feliz. La amenaza de la concordia a la comunidad se manifiesta a través de los devaneos acosadores del tendero hacia Antoinette y provocan la unión de todos y su apoyo a Antoine en la escena de la pelea. Esa cotidianeidad se atisba también en la excursión dominguera que aparece en ambas películas ${ }^{34}$ (Fig. 8). El segundo motivo sería el modo de tratar el mismo tema que la película que nos ocupa, la suerte y la felicidad, centrándose el relato, en este caso, en un billete de lotería perdido que genera la desgracia para la pareja protagonista del filme, aunque el final del mismo sea feliz como el de Navidades en julio ${ }^{35}$. El tercero radicaría en el valor ambiental y la presentación de un costumbrismo de postguerra con gente que quiere salir adelante de cualquier manera y que se agarra a un clavo ardiendo para buscar una vida mejor ${ }^{36}$. El billete de lotería, clave para mejorar de Se escapó la suerte, tiene su equivalente en los concursos y rifas de Esa pareja feliz.

33 En las primeras versiones de guion de Esa pareja feliz, Carmen trabajaba, al igual que Antoinette, en unos grandes almacenes.

34 Hay otros dos aspectos reseñables de Se escapó la suerte que influirán en otras películas de Berlanga y Bardem. Antoine y Antoinette, cuando se enteran que han ganado la lotería, escriben en un espejo con un pintalabios una lista de cosas que se quieren comprar con el dinero del premio que recuerda a "la lista a los Reyes Magos" que hacen los habitantes de Villar del Río en Bienvenido Mister Marshall. Por otro lado, cuando Antoine va a intentar cobrar el premio, en la oficina de la lotería hay un tipo afinand un piano que crea una sensación de estrés y nerviosismo que aparecerá en Isabel (Betsy Blair), la protagonista de Calle Mayor, en la secuencia previa al desenlace de la obra. Esta sensación proviene, sin ninguna duda, de la película frances

A este respecto es interesante la consulta de la siguiente obra: JEANCOLAS, J.P.: Histoire du cinema

35 français. París, Nathan Université, 1995, pp. 63-71. Interesa el capítulo que abarca desde la postguerra a los años cincuenta.

36 Jacques Becker era un director muy notable y la propia modestia de sus planteamientos, que le llevaban a huir de los "grandes temas", le convirtieron en un modelo para realizadores más jóvenes como François Truffaut, Claude Chabrol o el Jean Luc Godard de su primera etapa (1959-1964), y alguno

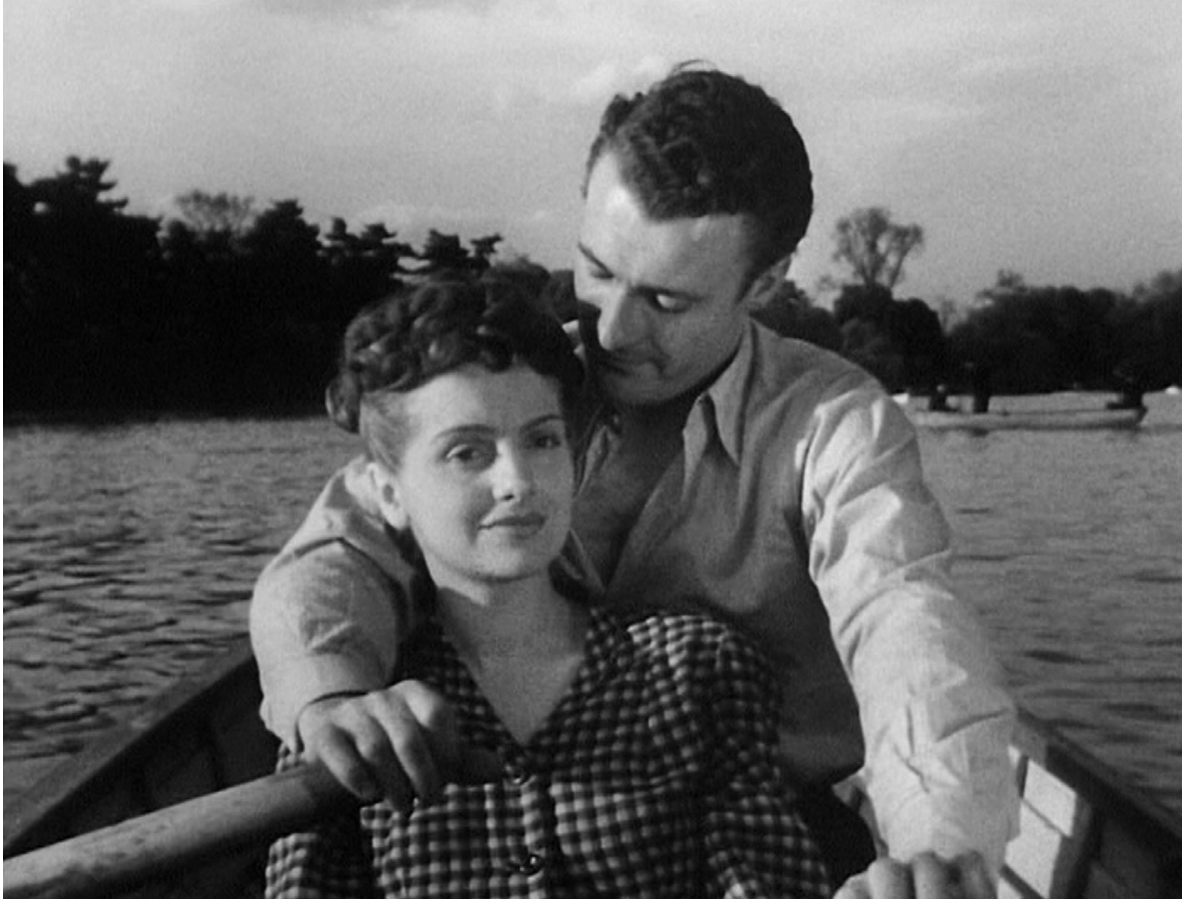

ig. 8: Antoine et Antoinette (Se escapó la suerte, 1946), de Jacques Becker. Excursión al campo de la pareja protagonista interpretada por Claire Maffei y Roger Pigaut

De hoy en adelante, de John Berry, es del mismo año que la película de Becker, pero se aleja del tono de comedia que impera en esta y en Navidades en julio. De nuevo, las similitudes entre este filme y Esa pareja feliz también son fundamentalmente argumentales, ya que también está protagonizada por una pareja humilde formada por Susan (Joan Fontaine) y Bill (Mark Stevens) que viven en el neoyorkino barrio del Bronx (Fig. 9). Como sucedía

otros de la Nouvelle Vague, que, en cierto modo, siempre estarán en deuda con Becker. La obra de este gran director siempre se caracterizó por su sentido del detalle y por su meticulosidad, así como su facilidad y habilidad en el manejo del tiempo y del espacio. 
en la película francesa y en la de Berlanga y Bardem, las duras condiciones de vida de la postguerra están presentes en ambos relatos, así como la incertidumbre respecto al futuro y a poder llevar una vida digna. Las humildes viviendas de postguerra y la estructura de la película en torno a flashbacks, son dos aspectos de Esa pareja feliz observables en el filme de John Berry, así como el uso de la voz en off del protagonista, que va guiándonos por el relato. Otras coincidencias entre la película estadounidense y la de Bardem y Berlanga son las secuencias en que los protagonistas son echados de sus trabajos o la de la efímera boda, así como las ensoñaciones que nos recuerdan los mejores tiempos pasados. El simbolismo de la lluvia y que el agua regenera es un mensaje presente en De hoy en adelante que se ve más en el final de Bienvenido Mister Marshall que en la propia Esa pareja feliz. Asimismo, los protagonistas del filme americano observan y recuerdan el devenir de la vida desde un puente del Bronx, al igual que Juan y Carmen lo hacen desde la azotea del bloque en el que viven, también van al cine como "la pareja feliz" y el film de Berry es culminado por un tema musical titulado como la película: From this Day Forward, que tiene su equivalente en la canción bufa de la película de Bardem y Berlanga que origina una pelea en el cabaret al que acuden los protagonistas en la parte postrera del filme.

Para finalizar con De hoy en adelante, esta obra era considerada por Javier Coma como "una emotiva crónica neorrealista", que evidentemente tuvo que ver en el marcado tono social del relato con la pareja protagonista de filme objeto de nuestro estudio ${ }^{37}$. Berry, que fue uno de los realizadores más perseguidos durante la "caza de brujas", consiguió una apreciable película, "sospechosa" a todas luces, por su carácter realista, en relación con el comunismo $^{38}$, aspecto más relacionable con la ideología y posterior trayectoria de Bardem que con el anarquismo burgués de Berlanga.

En lo que concierne a la relación de Esa pareja feliz con el cine de Frank Capra, es más fácil ver esta influencia en las siguientes obras de Berlanga como son Bienvenido Mister Marshall, Novio a la vista y Calabuch, que en el cine más dramático y crítico de Bardem. Al respecto de la relación del cine de Capra y la película que nos ocupa, Berlanga comentaba lo siguiente:

37 COMA, J.: El esplendor y el éxtasis. Historia del cine americano 2 (1930-1960). Barcelona, Laertes, 1993, p. 133.

38 RIAMBAU, E., "La posguerra y el maccarthysmo". Dentro de VV.AA.: J. Historia General del Cine Volumen VIII. Estados Unidos (1932-1955). Madrid, Cátedra, 1996, pp .82 y 111

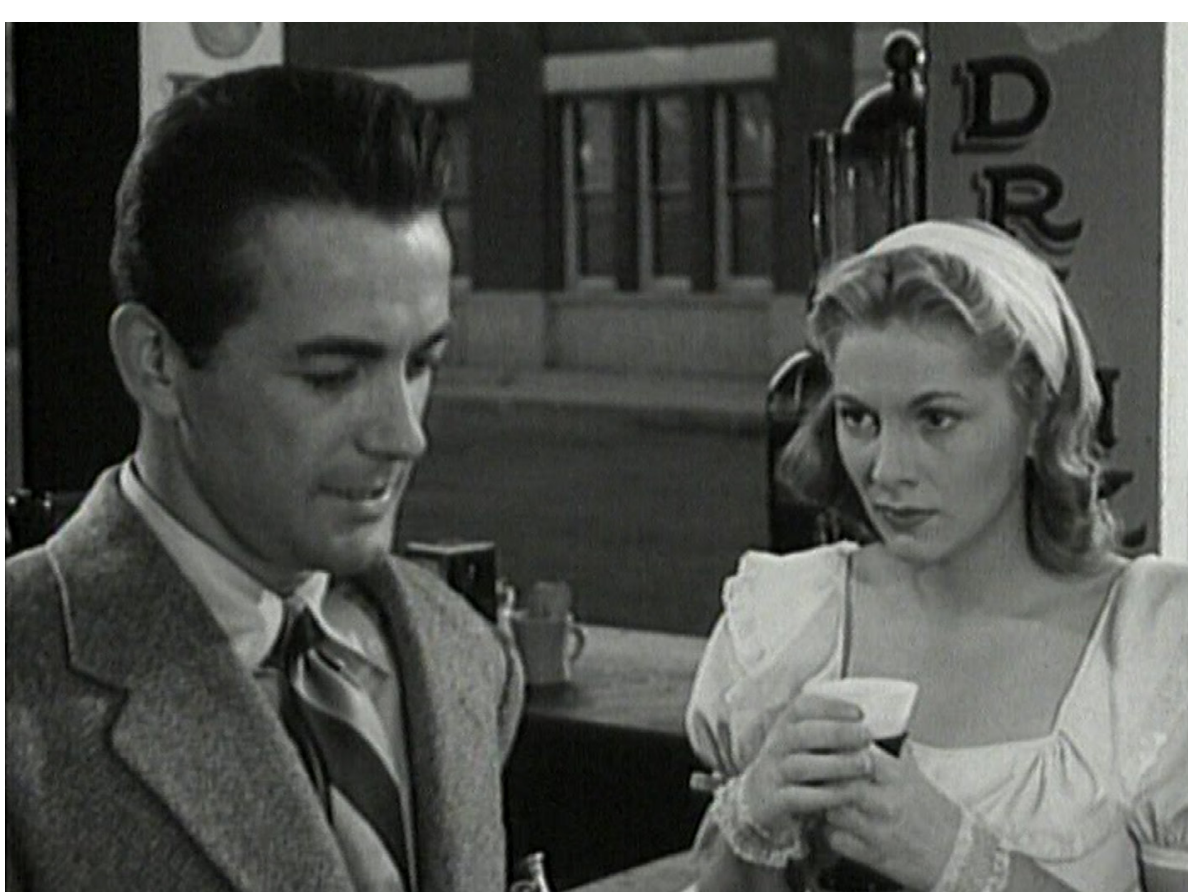

Fig. 9: From This Day Forward (De hoy en adelante, 1946), de John Berry. Mark Stevens y Joan Fontaine son la pareja protagonista

"Yo admiraba el cine de Capra desde muy joven; por eso si en Esa pareja feliz hay algo capriano se debe más a mí que a Bardem, porque a Juan Antonio no le gustaba ese anarquismo de derechas que presidía todo el cine y el mundo de Capra. Pero, aun así, yo creo que la película no puede compararse con las de Capra: a él le gustaban las películas alegres y optimistas, y nosotros quisimos hacer e hicimos, una película que resaltara las contradicciones que luego han presidido todo mi cine: la amargura y tristeza de unos personajes que, hagan lo que hagan, nunca van a poder superarse" ${ }^{39}$.

39 HERNÁNDEZ LES, J., e HIDALGO, M.: op. cit., p. 33. 
Un director español que influyó claramente a Bardem y Berlanga en sus primeros trabajos fue, según han reconocido ellos en diferentes ocasiones, Carlos Serrano de Osma, profesor del madrileño y del valenciano en el I.I.E.C. ${ }^{40}$. Serrano de Osma, que fue un auténtico ídolo para Bardem y Berlanga, puede que influyera en éstos en el excesivo detallismo de los guiones. El autor de Embrujo (1947), impartió dirección desde 1947 en la escuela de cine madrileña y tal fue su magisterio que la admiración que por él profesaban Bardem y Berlanga era grande (Fig. 10). En relación a Serrano de Osma, Bardem comentaba lo siguiente:

"Nuestro ídolo en aquellos momentos era Carlos Serrano de Osma, que para mí y para otros muchos, tenía la resonancia de la generación de los últimos años de la República. Carlos había sido de la F.U.E. y eso nos parecía la hostia ... Respecto a Cerco de $\mathrm{ira}^{41}$, uno de los mayores disgustos de mi vida me lo llevé por el hecho de que Serrano de Osma no me llevara como ayudante de dirección en esta película. Ahora puede parecer una tontería, pero en aquel momento significó un gran drama para mí"42.

Berlanga, por su parte, es mucho más explícito refiriéndose a la influencia de Serrano de Osma en la película que nos atañe:

"Colaboré en argumentos con Carlos Serrano de Osma. Bardem y yo en Esa pareja feliz planteamos un guion tan técnico como el que nos enseñó Serrano de Osma. Planificamos técnicamente la película entera dibujando hasta la planta de los personajes"43.

René Clair, es otro cineasta francés con el que tradicionalmente se ha relacionado el cine berlanguiano inicial en general, y Esa pareja feliz en particular. Quizás el rasgo más interesante de Clair que podemos vislumbrar en las primeras obras de Berlanga es la ternura que el director que nos ocupa otorga a sus personajes, a pesar de la sátira que nunca quedará fuera de la obra del valenciano. La admiración de Berlanga hacia el director francés queda clara en un famoso artículo que escribió en los comienzos de su carrera titulado Carta a un amigo que lee a Eisenstein, admira a René Clair y quiere ser director ${ }^{44}$

40 Sobre este director es de consulta obligada el libro de ARANZUBIA COB, A.: Carlos Serrano de Osma. Historia de una obsesión. Madrid, Filmoteca Española, 2007.

41 Película inacabada de Serrano de Osma en que trabajaron junto a él Bardem y Berlanga.

42 CASTRO, A. El cine español en el banquillo. Fernando Torres editor. Valencia 1974, p. 58. La cita procede de una entrevista que el autor del libro hace, en este caso, a Juan Antonio Bardem.

43 SOJO GIL, K.: Americanos... op. cit., p. 320

44 La referencia concreta es BERLANGA, L.G.: "El cine en la pizarra. El IIEC. Carta a un amigo que lee Eisenstein, admira a René Clair y quiere ser director". Revista internacional de cine. 1 de junio de 1952

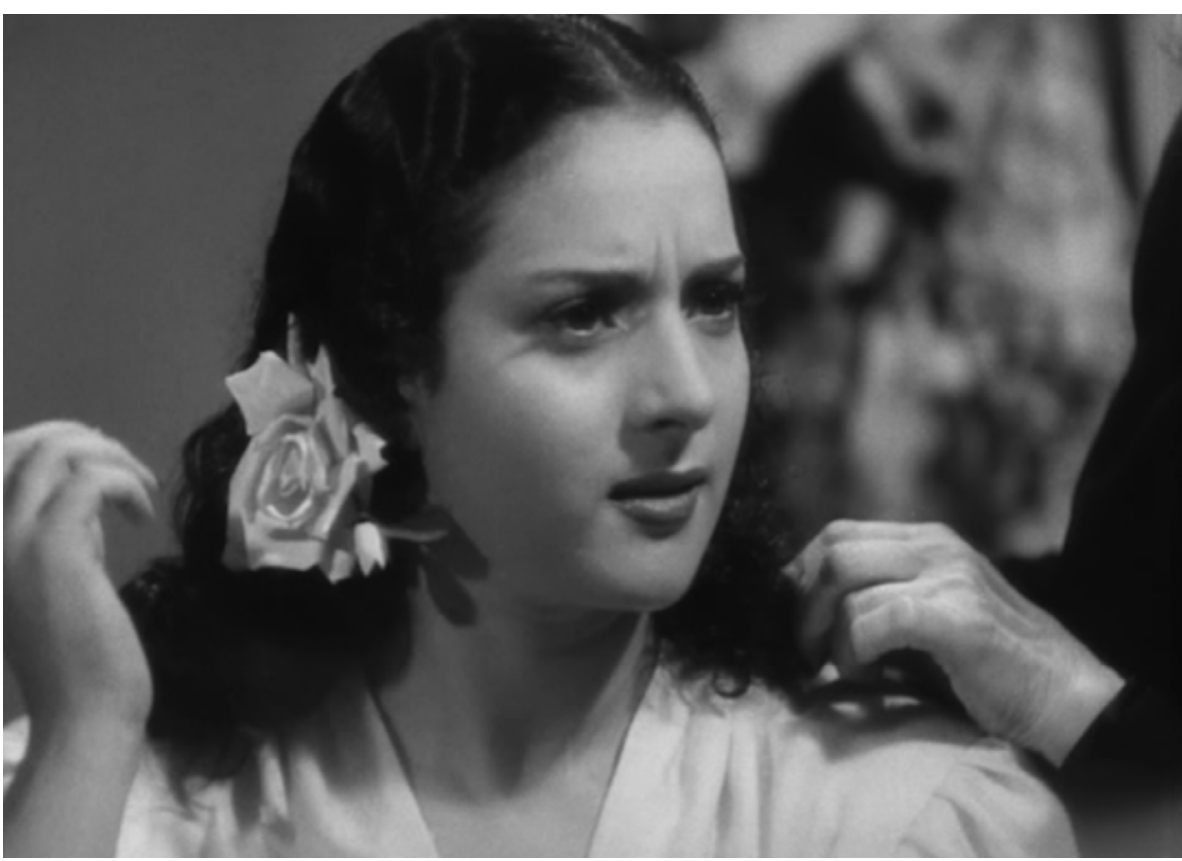

Fig. 10: Embrujo (1947), de Carlos Serrano de Osma con una joven Lola Flores encabezando el reparto

Concretamente, el artículo estaba firmado en 1952. Berlanga siempre ha afirmado que al director francés le gustaban mucho sus películas ${ }^{45}$. Años más tarde, el valenciano y Clair coincidirían en la codirección de la película colectiva Las cuatro verdades, filme compuesto por cuatro sketches, tendencia muy de moda a inicios de los 60 , dos de los cuales eran obra de estos dos directores y que estaban basados en las fábulas de Lafontaine ${ }^{46}$.

Respecto a la evidente relación entre Esa pareja feliz, las carreras incipientes de Berlanga y Bardem, y el neorrealismo italiano, no vamos a insistir mucho porque sobre este tema ya se ha hablado largo y tendido en otras ocasiones ${ }^{47}$. Simplemente es preciso citar la relación

45 HERNÁNDEZ LES, J. e HIDALGO, M.: op. cit., p. 45

46 Los otros dos directores eran Alessandro Blasetti y Hervé Bromberger

47 SOJO GIL, K.: Americanos... op. cit., pp. 181-186. 
que se establece entre los directores que nos ocupan y el guionista Cesare Zavattini que asiste como ponente a una semana de cine trasalpino que se organiza en Madrid en 1951, organizada por el Instituto Italiano de la capital de España ${ }^{48}$, que impresiona mucho a los entonces jóvenes directores de Esa pareja feliz, así como la escritura de algunos guiones en común con el gran guionista italiano como Cinco historias de España y El gran festival, que finalmente no fructifican. La mayor diferencia entre el neorrealismo italiano y el neorrealismo a la española estribaba en que Italia estaba sumida en una dura postguerra, pero el fascismo había sido superado, mientras que España, en su postguerra, tenía que soportar el franquismo y la falta de libertades que aparejaba, entre las que destacaba la voraz y coercitiva acción de la censura. Además, el cine colosalista y grandilocuente había sido erradicado de Italia con una nueva visión de la realidad, mientras que en España era un modelo de cine promocionado por el gobierno para afirmar su política totalitaria.

\section{REFERENTES LITERARIOS DE ESA PAREJA FELIZ}

No solamente son cinematográficos los referentes de los autores que nos ocupan para llevar a cabo el filme que centra nuestro interés en esta publicación, ya que la literatura también ha sido citada como influencia recibida por Bardem y Berlanga para hacer Esa pareja feliz. De ese modo, se aprecia una relación evidente entre el sainete de Carlos Arniches y la película, relación más que patente en la filmografía berlanguiana de los 50 y menos presente en la obra de Bardem. El sainete, que es heredero del entremés de los siglos XVI y XVII y posteriormente, el teatro grotesco, engarza claramente con la tradición española de la picaresca, y con el cine del primer Berlanga. Por las obras de Arniches pasan cientos de personajes, docenas de ambientes diferentes, niños que sufren por hambre, por incomprensión o por soledad, mujeres que suplen con amor y, en ocasiones con rabia -que es prólogo de rebeldía-, la falta de otras muchas cosas, hombres jóvenes con permanente ilusión, pero con continuas decepciones y hombres viejos a quienes las decepciones han hecho olvidar la ilusión. En Arniches la caricatura se humaniza, a diferencia del mundo teatral de don Ramón de la Cruz. En Berlanga sucede algo parecido a lo largo de la primera parte de su obra. Como decía de Arniches José Bergamín:

48 Ibid., pp. 184 y 252 "el teatro grotesco de Arniches, radica su autenticidad, su verdad dramática, en esa máscara que, paradójicamente, desenmascara lo humano al transparentarlo, porque lo profundiza y amplía para los ojos y para los oídos: para su entendimiento"49.

Se trata de ofrecer al espectador una sociedad -ante la que el autor toma postura, negándose a aceptarla porque le resulta negativa-, a través de unos personajes que, bajo una capa de comicidad, de ridiculez, de estilización grotesca, muestran los problemas, los conflictos, la angustia de unas situaciones de signo trágico. Unión de lo risible y lo patético o como decía Salinas: "de comicidad externa y gravedad profunda"50.

Según Román Gubern, respecto a la relación entre Arniches y el cine del valenciano, en la obra de Berlanga se suprime la jerarquización del diálogo porque se presenta con la misma simultaneidad de espacios y personajes que se presentaba en Arniches. Gubern dice lo siguiente acerca de Arniches y Berlanga:

"yo recuerdo que cuando se estrenó en España Esa pareja feliz, Luis declaró que con Bardem había intentado hacer una película entre Arniches y René Clair. Lo de Arniches nos sitúa mucho porque existe un elemento popular que se remonta al cine español de la República. Arniches era también levantino como Berlanga, aunque ejerció como madrileñista militante. Pues bien, el cine de Berlanga se emparenta con Edgar Neville, quien llevó en 1935 a la pantalla una obra de Arniches como La señorita de Trevélez, que luego, Bardem reconstruiría en su Calle Mayor... Con esto quiero decir que en la anteguerr Arniches encarnaba un modelo de espectáculo popular, que impregnó a los cineastas más importantes de la República. Y estas raíces tienen su continuidad claramente en Berlanga, cuyos filmes prolongan la mejor tradición del cine liberal-popular de la República, el de Filmófono, Neville, Perojo y Marquina"51. 


\section{ESA PAREJA FELIZ COMO REFERENTE DE CINE POSTERIOR}

Como no podía ser de otra manera, al ser Esa pareja feliz una película importante de la historia del cine español, el filme de Bardem y Berlanga también ejercerá un influjo evidente en algunas obras cinematográficas posteriores como las dos películas dirigidas e interpretadas por Fernando Fernán Gómez a finales de la década de los 50. Nos referimos a La vida por delante y a la secuela de ésta La vida alrededor. La diferencia entre el filme de Berlanga y Bardem y los de Fernán Gómez estriba en que en el primero la pareja protagonista intenta salir adelante en la postguerra, mientras que en las dos siguientes el contexto de 1959 se encuadra ya en el pre-desarrollismo de la década de los 60. Como diferencia también es preciso decir que el matrimonio de Esa pareja feliz es muy humilde, mientras que el de los filmes de Fernán Gómez no es tan modesto, aunque tienen que afrontar los mismos problemas que su referente: vivienda, trabajo, vida en pareja, etc. Fernán Gómez, partícipe en los dos proyectos y acompañado por la actriz argentina Analí Gadé en esta ocasión, ha reconocido la influencia recibida de Esa pareja feliz para hacer sus dos películas de la siguiente forma:

"Debo reconocer que si no existiera Esa pareja feliz es muy probable que yo no hubiese hecho La vida por delante; ambas, Esa pareja feliz y La vida por delante son producto del shock que en nosotros representó el neorrealismo italiano frente al cine standard americano. (...) S trata de un neorrealismo más tamizado por el paso de los años. El ángulo de humor con el que se contemplan las cosas en La vida por delante es más acusado. Es también mucho más satírica y más irónica. Hay una menor servidumbre al realismo fotográfico que surgió como secuela del neorrealismo italiano"52.

Otra película que es deudora de la idea planteada en Esa pareja feliz y que también se ubica en un pre-desarrollismo con grandes problemas de vivienda es El inquilino, de José Antonio Nieves Conde. De nuevo, Fernando Fernán Gómez es el marido de una pareja con problemas que parece una prolongación del matrimonio del filme de Bardem y Berlanga. En esta ocasión su atribulada esposa fue interpretada por María Rosa Salgado.
Para finalizar, esperamos que esta publicación sirva para reivindicar la importancia de Esa pareja feliz en la irrupción de una nueva manera de hacer cine en la España de los 50, y para recordar que los jóvenes entonces Berlanga y Bardem fueron inspirados por películas, directores, tendencias cinematográficas, ideológicas y literarias sin las cuales habría sido imposible la génesis y posterior filmación de una pequeña película cuya importancia en el contexto general del cine español, ha ganado con el inexorable paso del tiempo.

52 HEREDERO, C. F.: op. cit., p.359. 


\section{BIBLIOGRAFÍA}

ALSINA THEVENET, H.: Historia del cine americano /1. (1893-1930). Desde la creación al primer sonido, Barcelona, Laertes, 1993.

ARANZUBIA COB, A.: Carlos Serrano de Osma. Historia de una obsesión. Madrid, Filmoteca Española, 2007.

CAÑEQUE, C. y GRAU, M.: Bienvenido Mr. Berlanga. Barcelona, Destino, 1993.

CASTRO, A.: El cine español en el banquillo. Valencia, Fernando Torres editor, 1974.

CERÓN GÓMEZ, J.F.: El cine de Juan Antonio Bardem. Murcia, Universidad de Murcia y Primavera cinematográfica de Lorca, 1998.

COMA, J.: El esplendor y el éxtasis. Historia del cine americano 2 (1930-1960), Barcelona, Laertes, 1993.

ECHART, P.: La comedia romántica del Hollywood de los años 30 y 40, Madrid, Cátedra, 2005

FANÉS, F.: "Al voltant d'una sequencia de Esa Pareja Feliz", en PÉREZ PERUCHA, J.: Berlanga II. Sobre Luis García Berlanga. Comunicaciones y debates, Valencia, Archivo Municipal y Ayuntamiento de Valencia, 1981.

GARCÍA LORENZO, L.: El teatro español hoy. Barcelona, Planeta, 1995.

GÓMEZ RUFO, A.: Berlanga. Contra el poder y la gloria. Escenas de una vida, Madrid, Temas de hoy, 1990.

GUBERN, R.: "Esa pareja feliz", en PÉREZ PERUCHA, J.: Antología crítica del cine español (1906-1995), Madrid, Cátedra y Filmoteca Española, 1997.

HEREDERO, C. F.: Las huellas del tiempo. Cine español. 1951-1961, Madrid. Filmoteca española y Filmoteca de la Generalitat Valenciana, 1994.

HERNÁNDEZ LES, J. e HIDALGO, M.: El último austro-húngaro. Conversaciones con Berlanga. Barcelona, Anagrama, 1980.
JEANCOLAS, J.P.: Histoire du cinema français, París, Nathan Université, 1995.

MONTERDE, J.E.: "El cine de la autarquía", en GUBERN, R. y otros.: Historia del cine español. Madrid, Cátedra, 2010

RIAMBAU, E.: "La posguerra y el maccarthysmo", en VV.AA.: Historia General del Cine. Volumen VIII. Estados Unidos (1932-1955). Madrid, Cátedra, 1996.

RIAMBAU, E., y TORREIRO, C.: Productores en el cine español. Madrid, Cátedra y Filmoteca Española, 2008.

SALVADOR MARAÑÓN, A.: De Bienvenido Mister Marshall a Viridiana. Historia de Uninci: una productora cinematográfica española bajo el franquismo. Madrid, Egeda y 8 y medio, 2006.

SOJO GIL, K.: Americanos os recibimos con alegría. Una aproximación a Bienvenido Mister Marshall. Madrid, Notorious, 2009.

SOJO GIL, K.: "El cine historicista del primer franquismo y su relación con la decimonónica Pintura de Historia: El caso del plano final de Locura de amor (1948)", en VÉLEZ CHAURRI, J.J., ECHEVERRIA GOÑI, P. y MARTINEZ DE SALINAS, F.: Estudios de Historia del Arte en memoria de la profesora Micaela Portilla. Vitoria-Gasteiz, Diputación Foral de Álava, 2008, pp. 471-498.

SOJO GIL, K.: El verdugo. Guía para ver y analizar. Valencia, Nau Llibres, 2016.

SOJO GIL, K.: "Imagen translucida de la ciudad provinciana franquista a través del plano final de Calle Mayor (1956), de Juan Antonio Bardem”, en PEYRAGA, P., GAUTREAU, M., PEÑA, C y SOJO GIL, K.: La imagen translúcida en los mundos hispánicos. Villeurbanne, Orbis Tertius, 2016, pp.439-457.

SOJO GIL, K.: "La censura en el cine español del franquismo. El caso de Los jueves milagro (1957), de Berlanga", en GUEREÑA, J.L. y ZAPATA, M.: Censures et manipulations dans les mondes ibérique et latino-américain, Tours, PUFR, 2013, pp.175-192.

SOJO GIL, K.: "Se vende un tranvía (1959), o el comienzo de la época dorada de Luis García Berlanga”, Cuadernos Cinematográficos. Vol. 10, Universidad de Valladolid, 1999, pp. 37-42. 